\title{
THE TREATMENT OF FRACTURE-SEPARATION OF THE CAPITULAR EPIPHYSIS
}

\author{
W. A. Crabbe, London, England \\ From Guy's Hospital, London
}

It has long been recognised that displaced fractures of the capitular epiphysis in children are prone to non-union and late deformity unless accurate reduction is obtained. Good results have been reported from conservative treatment (Kini 1942, McLearie and Merson 1954), but it is generally accepted that to obtain the best results open reduction is necessary. Some form of internal fixation is also advisable to prevent the pull of the common extensor muscles redisplacing the fragment. Internal fixation may be by suture of the extensor origin to the periosteum of the proximal fragment (Badger 1954, Watson-Jones 1955), or by fixation with screws or wire (Jeffery 1955, 1957, 1958; Wilson 1955).

The present review was undertaken to determine if there was, in fact, any difference in the result obtained by the use of either soft-tissue suture or metallic fixation.

\section{MATERIAL}

Seventeen children with capitular fracture-displacement treated by operation were examined personally between six months and seven years after the injury, the average length of follow-up being two and a half years. The method of internal fixation used is given in Table I. It was usual to use one or two sutures of chromic catgut when this method was chosen.

TABLE I

Detalls of Seventeen Children with Displacement of the Capitular EPIPHYSIS

\begin{tabular}{|c|c|c|c|}
\hline Side injured* & 13 left & \multicolumn{2}{|c|}{4 right } \\
\hline Sex & 16 boys & \multicolumn{2}{|c|}{1 girl } \\
\hline Age range & $3-9$ years & \multicolumn{2}{|c|}{ Average 5.6 years } \\
\hline \multirow[t]{3}{*}{ Type of fixation } & Catgut & ature . & 11 \\
\hline & Kirsch & wire & . 5 \\
\hline & Steel $p$ & & 1 \\
\hline
\end{tabular}

${ }^{*}$ Fourteen children were right handed.

It is interesting that the injury was predominantly left sided although most of the patients were right handed, which suggests that the fall on to the left hand occurred while the right hand was holding something, but the actual mechanism could not be elucidated from the case histories.

\section{RESULTS}

The results were uniformly good except in Case 1 in which non-union followed failure to reduce the fracture adequately at operation (Table II, Figs. 1 and 2). 
In the remaining patients the elbow was either normal on clinical examination or showed only the slightest restriction of movement. Cases 6 and 15 had some varus deformity and Case 7 had a slight valgus deformity but in no child was the deformity unsightly or disabling.

TABLE II

Details of the Treatment and Result of Seventeen Children with Fracture-Separation of the Capitulum

\begin{tabular}{|c|c|c|c|c|c|c|c|c|}
\hline $\begin{array}{c}\text { Case } \\
\text { number }\end{array}$ & Sex & $\begin{array}{c}\text { Age } \\
\text { (years) }\end{array}$ & Side & $\begin{array}{l}\text { Length of } \\
\text { follow-up } \\
\text { (months) }\end{array}$ & Symptoms & Deformity & Radiographs & Comment \\
\hline \multicolumn{9}{|c|}{ Cases treated by suture } \\
\hline 1 & Boy & 4 & Left & 24 & None & Slight & Non-ur.ion & $\begin{array}{l}\text { A stable joint with loss of } 5 \mathrm{de}- \\
\text { grees of flexion and extension. } \\
\text { See Figures } 1 \text { and } 2\end{array}$ \\
\hline 2 & Boy & 4 & Right & 22 & None & None & Union & See Figures 3 and 4 \\
\hline 3 & Boy & 6 & Left & 22 & None & None & Union & - \\
\hline 4 & Boy & 6 & Left & 21 & None & Very slight & Union & Very slight loss of extension \\
\hline 5 & Girl & 6 & Left & 36 & None & None & Union & - \\
\hline 6 & Boy & 6 & Left & 32 & None & Slight & Union & $\begin{array}{l}5 \text { degrees loss of flexion } \\
\text { and very slight varus }\end{array}$ \\
\hline 7 & Boy & 9 & Left & 32 & None & Very slight & Union & Very slight increase in valgus \\
\hline 8 & Boy & 8 & Right & 8 & None & None & Union & - \\
\hline 9 & Boy & 3 & Left & 84 & None & Slight & Union & Very slight loss of supination \\
\hline 10 & Boy & 6 & Left & 72 & None & Slight & Union & Very slight loss of extension \\
\hline 11 & Boy & 5 & Left & 14 & None & None & Union & - \\
\hline \multicolumn{9}{|c|}{ Cases treated by wires or pin } \\
\hline 12 & Boy & 3 & Right & 8 & None & None & Union & $\begin{array}{l}\text { Treated with a stainless steel } \\
\text { domestic pin }\end{array}$ \\
\hline 13 & Boy & 3 & Left & 6 & None & Slight & Union & $\begin{array}{l}5 \text { degrees loss of extension. } \\
\text { Wire extruded at three weeks } \\
\text { after operation }\end{array}$ \\
\hline 14 & Boy & 5 & Left & 37 & None & None & Union & $\begin{array}{l}\text { The Kirschner wire had to be } \\
\text { removed later }\end{array}$ \\
\hline 15 & Boy & 5 & Left & 38 & None & Yes & Union & $\begin{array}{l}10 \text { degrees varus, that is, } 20 \text { degrees } \\
\text { difference between left and right } \\
\text { elbows }\end{array}$ \\
\hline 16 & Boy & 6 & Left & 29 & None & None & Union & $\begin{array}{l}\text { The Kirschner wire had to be } \\
\text { removed later }\end{array}$ \\
\hline 17 & Boy & 5 & Right & 51 & None & Slight & $\begin{array}{l}\text { Union. } \\
\text { Epiphysial } \\
\text { irregularity }\end{array}$ & $\begin{array}{l}\text { The two Kirschner wires used } \\
\text { had to be removed later }\end{array}$ \\
\hline
\end{tabular}

The radiological results, with the exception of Case 1, were uniformly good. A typical example is shown in Figures 3 and 4.

VOL. 45 B, NO. 4, NOVEMBER 1963 
When wire was used it was removed from four out of five elbows because extrusion started. In the other patient it extruded spontaneously at about the third week (Case 13). The pin used in Case 12 was still in place eight months after operation.

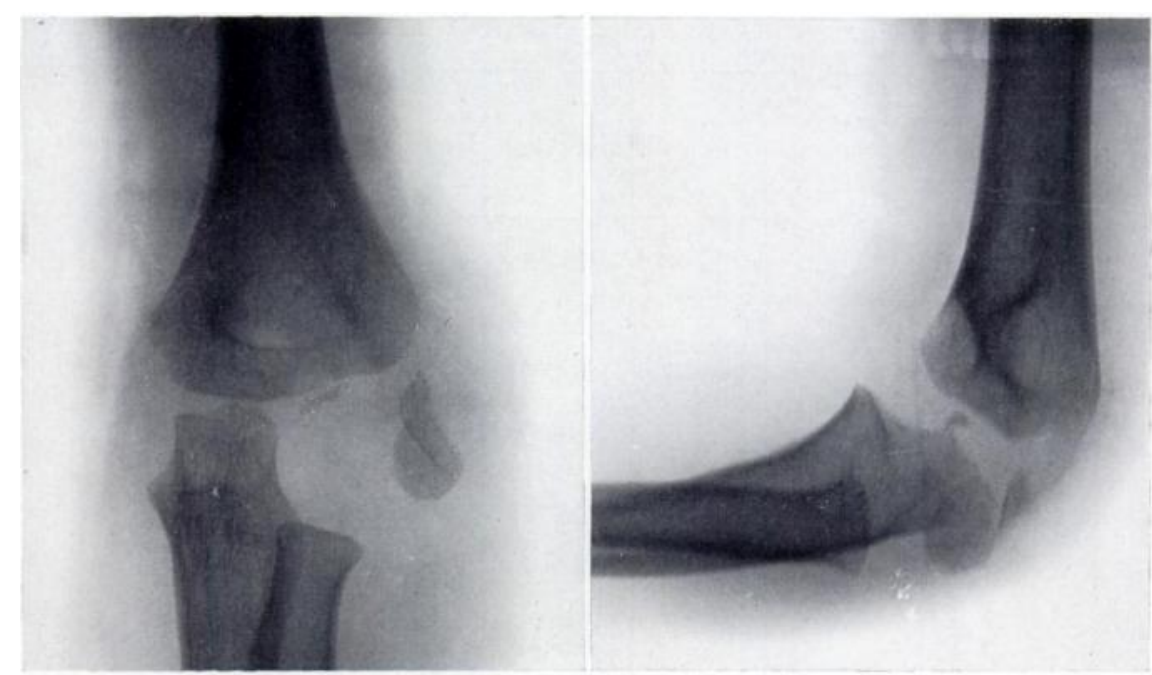

FIG. 1

Case 1-Displaced left capitulum in a boy of four years.

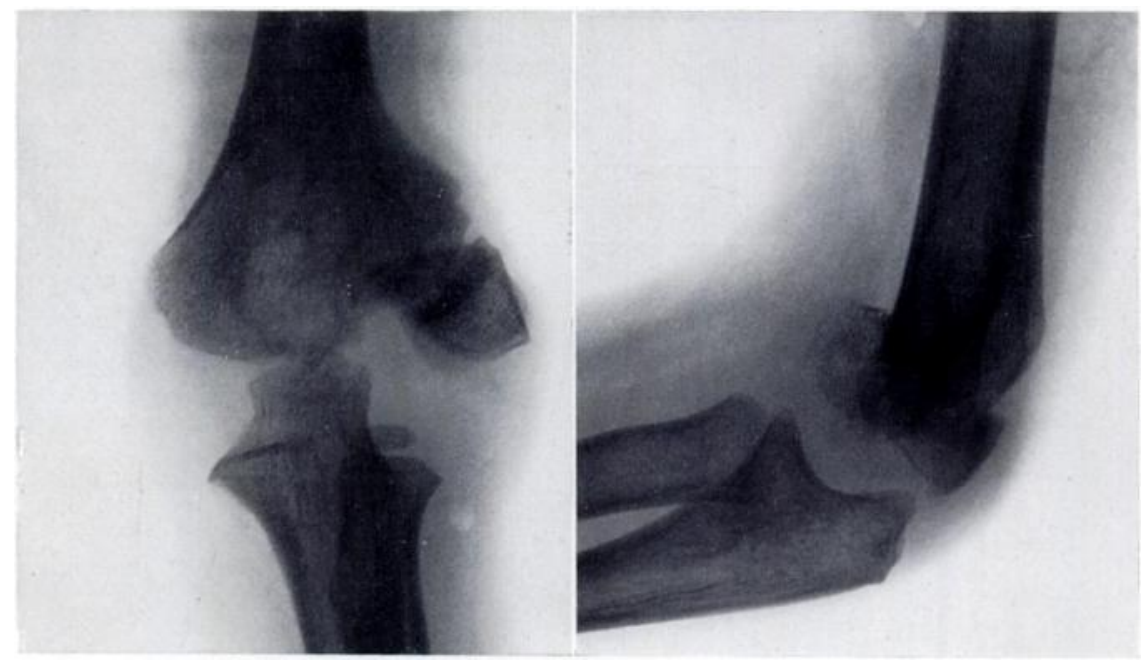

FIG. 2

Case 1 -Non-union of the fragment, because of inadequate reduction, two years later.

\section{DISCUSSION}

One operation failed (Case 1) because the displacement was not reduced at operation and this was avoidable. In the other ten patients treated by suture the results were good and compare favourably with wire or pin fixation. Jeffery (1958) pointed out that bad results 
with non-union occurred in those patients with undisplaced fractures which were either untreated or treated inadequately. He also said that bad results might follow attempts at manipulation or fixation by suture but the latter is not supported by this report.

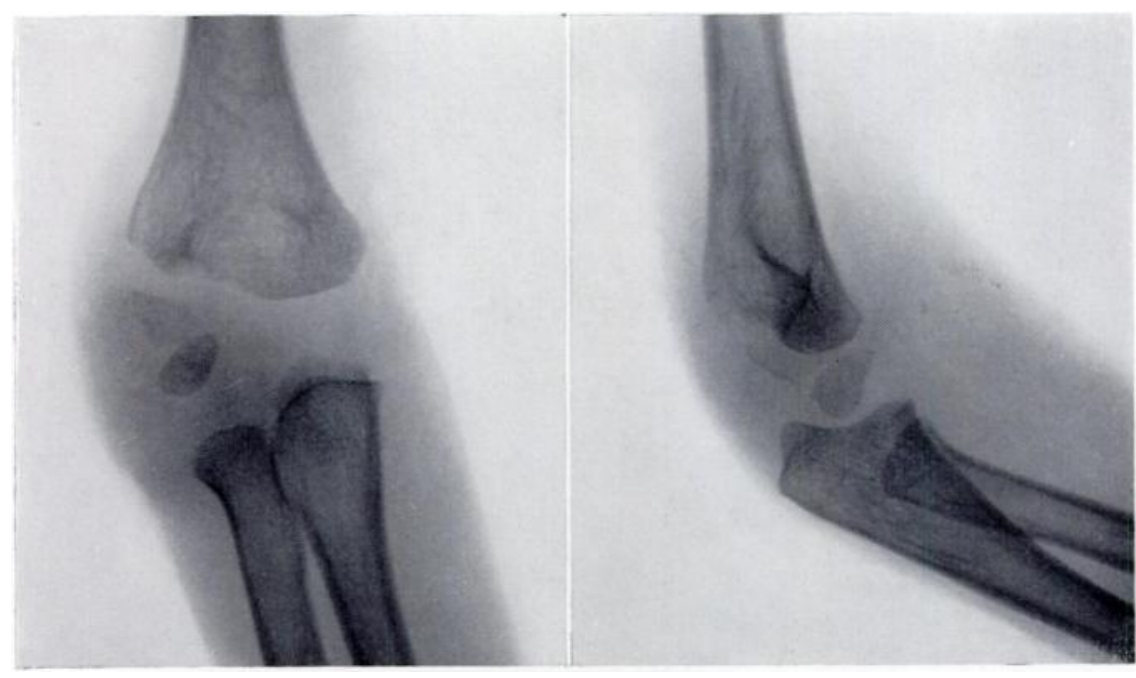

Fig. 3

Case 2-Displaced right capitulum in a boy of four years.

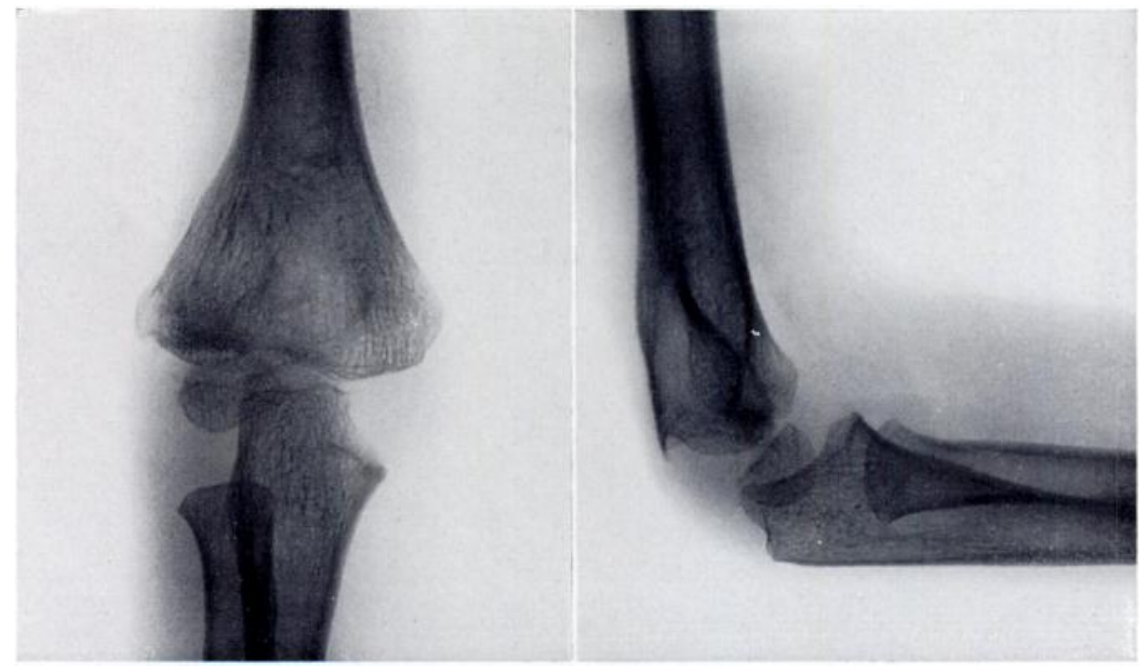

FIG. 4

Case 2-The position twenty-two months after suture.

Good results can be obtained in the treatment of this injury by any of the accepted methods at present in use but fixation of the fragment by suture deserves wider popularity because it gives good results, is technically simple and is devoid of the complications of wire fixation.

VOL. 45 B, NO. 4, NOVEMBER 1963 


\section{SUMMARY}

1. Seventeen children with fracture-separations of the capitular epiphysis are reviewed.

2. Soft-tissue suture was used in eleven and metallic fixation in six children.

3. There was one bad result because of faulty technique but all the other children obtained good results.

4. Soft-tissue suture was found to be a simple procedure with none of the complications of wire fixation.

I should like to thank Mr J. S. Batchelor, Mr P. G. Epps, Mr T. T. Stamm, Mr J. K. Stanger and Mr O. J. Vaughan-Jackson for permission to examine and report upon their patients.

\section{REFERENCES}

BADGer, F. G. (1954): Fractures of the Lateral Condyle of the Humerus. Journal of Bone and Joint Surgery, 36-B, 147.

JefFery, C. C. (1955): Fracture-separation of the Lateral Condylar Epiphysis of the Humerus. Journal of Bone and Joint Surgery, 37-B, 350.

JefFery, C. C. (1957): Non-union of the Epiphysis of the Lateral Condyle of the Humerus. Journal of Bone and Joint Surgery, 39-B, 582.

JefFery, C. C. (1958): Non-union of the Epiphysis of the Lateral Condyle of the Humerus. Journal of Bone and Joint Surgery, 40-B, 396.

KINI, M. G. (1942): Fractures of the Lateral Condyle of the Lower End of the Humerus with Complications. Journal of Bone and Joint Surgery, 24, 270.

MCLearie, M., and Merson, R. D. (1954): Injuries to the Lateral Condyle Epiphysis of the Humerus in Children. Journal of Bone and Joint Surgery, 36-B, 84.

Watson-JONES, Sir R. (1955): Fractures and Joint Injuries. Fourth edition. Volume 2, p. 539. Edinburgh and London: E. \& S. Livingstone Ltd.

WiLson, J. N. (1955): Fractures of the External Condyle of the Humerus in Children. British Journal of Surgery, 43, 88.

Wilson, P. D. (1936): Fracture of the Lateral Condyle of the Humerus in Childhood. Journal of Bone and Joint Surgery, 18, 301. 